\title{
The Role of Epstein-Barr Virus LMP-1 Immunohistochemical Staining in Childhood Hodgkin Lymphoma
}

\author{
Hikmet Gulsah Tanyildiz, ${ }^{1, *}$ Inci Yildiz, ${ }^{1}$ Nuray Bassullu, ${ }^{2}$ Nukhet Tuzuner, ${ }^{2}$ Alp Ozkan, ${ }^{1}$ Tiraje \\ Celkan, and Hilmi Apak ${ }^{1}$ \\ ${ }^{1}$ Department of Pediatric Hematology/Oncology, Cerrahpasa Medical Faculty, Istanbul University, Istanbul, Turkey \\ ${ }^{2}$ Department of Pathology, Cerrahpasa Medical Faculty, Istanbul University, Istanbul, Turkey \\ ${ }^{*}$ Corresponding author: Hikmet Gulsah Tanyildiz, Department of Pediatric Hematology/Oncology, Cerrahpasa Medical Faculty, Istanbul University, Istanbul, Turkey. Tel: +90- \\ 5058731636;+90-3123056182, E-mail: g_oktay4910@yahoo.com
}

Received 2015 May 21; Revised 2015 September 7; Accepted 2015 September 20

\begin{abstract}
Background: There are a few published studies about prognostic markers of Epstein-B virus (EBV) related to outcomes in pediatric Hodgkin Lymphoma (HL).

Objectives: We aimed to investigate the prognostic value and effect of EBV on survival by using biopsy materials in children and adolescents diagnosed with HL.

Patients and Methods: EBV LMP-1 expression was examined using immunohistochemical methods in 58 tumor samples. Clinical features, overall survival (OS) and failure free survival time (FFS) were compared between EBV LMP-1 positive and negative patients.

Results: In 20 (35\%) patients tumors were LMP-1 positive. When compared with patients above 10 years old, EBV LMP-1 was often positive in patients under 10 years old ( $30 \% \mathrm{vs.} 70 \%, \mathrm{P}=0.02$ ). In our most cases having $\mathrm{B}$ symptoms and advanced stage, $\mathrm{EBV}$ positiveness in Hodgkin Reed-Stenberg cells $(\mathrm{H}-\mathrm{RS})$ was not a significant determinant for survival $(\mathrm{P}=0.78)$. Half of the past clinical trials in childhood HL reported longer survival rates in EBV LMP-1 positive patients. In some trials similar to our results there was no significant relationship between EBV and prognosis.

Conclusions: The reason of diminished EBV positiviness may be related to technical methods such as not using immunohistochemical and in situ hybridization for EBER antigen but in laboratory conditions painting of control tissues with EBV impair this probability. In addition, cases enrolled to our study were living in Istanbul where social and economical factors are improved rather than generally.
\end{abstract}

Keywords: Hodgkin Lymphoma, EBV, Prognosis

\section{Background}

Hodgkin Lymphoma (HL) is a heterogenous disease composed of many etiological factors. Especially in adults many clinical trials were designed evaluating factors associated with clinical course, pathogenesis and etiology. Such studies are limited in pediatric HLs to clarify useful indicators about its etiology, prognostic factors, response to treatment, prognosis and survival such as protooncogenes and EBV. International prognostic score system (IPSS) was developed for classifying the adult patients according to their risk profiles and hypoalbuminemia, anemia, leukocytosis, lymphopenia, stage 4 disease, male gender, and age over 45 years were considered as high risk criteria (1).

In addition to this risk scale, there are many clinically developed markers used as prognostic determinants related to tumor progression. Results of clinical trials are inconsistent with the role of EBV for the pathogenesis of HL. Some of them support the relationship between EBV and HL (2-4) whereas the others show no correlation between the two parameters (5-8).

\section{Objectives}

We aimed to investigate the prognostic value and effect of EBV on survival by using biopsy materials in children and adolescents diagnosed with HL.

\section{Materials and Methods}

Between the time period 1997 and 2012, 192 patients diagnosed with HL disease were screened retrospectively in Clinics of Pediatric Oncology, Cerrahpasa Medical Faculty and 58 of them under 18 years of age, were included in the study according their compliance to the clinical follow-up regularly and availability of patient information and pathological samples properly. Distribution of 58 patients were homogeneous by year.

Clinical examination, chest X-ray, contrast enhanced computerized tomography of chest, abdomen, Galium-67, PET $\mathrm{CT}$ and pelvis and unilateral iliac crest bone marrow biopsy were applied for clinical staging as per Ann Arbor criteria.

Copyright (c) 2015, Growth \& Development Research Center. This is an open-access article distributed under the terms of the Creative Commons Attribution-NonCommercial 4.0 International License (http://creativecommons.org/licenses/by-nc/4.0/) which permits copy and redistribute the material just in noncommercial usages, provided the original work is properly cited. 
Patients received 6 - 8 cycles of ABVD (doxorubicin, bleomycin, vinblastine, dacarbazine) treatment. Six relapsed patients received COPP or MOPP regimen besides ABVD regimen. With the exception of four, all other patients received additional radiotherapy.

Complete remission was defined as the complete regression of all clinical or radiological evidence of HL. Progressive disease was defined as an increase of at least $25 \%$ of the size of a measurable lesion or the appearance of a new lesion. Overall survival (OS) was calculated from the time of diagnosis to the last visit of the patient or occurrence of death from any cause and disease progression on therapy. Relapse was recorded as an event for failure free survival (FFS).

Immunohistochemistry was performed on formalinfixed paraffin-embedded tissues from diagnostic biopsies with monoclonal antibodies against LMP-1. For LMP1, clone CS1-4 from Genetex was used in a 1:25 dilution. The expression of LMP-1 was systematically reviewed in a semiquantitative way by 2 pathologists working without access to the clinical data. Detection of a single Reed Steinberg cell staining pattern was considered positive.

\subsection{Statistical Methods}

SPSS 15 version software was used for the data analysis. For the univariate analysis, Fisher's exact test was used to assess the association between categorical variables. For ordinal data, non-parametric tests were used. Survival curves were estimated using the Kaplan-Meier method and differences between curves were evaluated with the log-rank test. A multivariate survival analysis was performed with Cox's stepwise proportional hazards model. $\mathrm{P}$ value less than 0.05 was considered as statistical significance level.

\section{Results}

The study population included 32 (55\%) boys and 26 (45\%) girls. The median age at diagnosis was 11 (range 3 - 16) years. Advanced stage, defined as Ann Arbor stages IIB-IV, was present in $47 \%$ of the patients. B symptoms were seen in $53 \%$ cases. The most frequent (50\%) histological subtype of HL was nodular sclerosis. The complete remission rate of the whole series was $79 \%$ with a median follow up of 55 (range 4 -138) months. Because of disease progression 8 patients died. The patients' clinical characteristics at diagnosis are listed in Table 1.

\begin{tabular}{|c|c|}
\hline Characteristic & Frequency $^{\mathbf{a}}$ \\
\hline \multicolumn{2}{|l|}{ Gender } \\
\hline Female & $26(45)$ \\
\hline Male & $32(55)$ \\
\hline \multicolumn{2}{|l|}{ Histology } \\
\hline Noduler sclerosis & $29(50)$ \\
\hline Mixed cellularity & $20(34)$ \\
\hline Lymphocyte-rich cHL & $1(2)$ \\
\hline Lymphocyte depletion & $2(4)$ \\
\hline Noduler lymphocyte rich HL & $6(10)$ \\
\hline \multicolumn{2}{|l|}{ Clinical stage } \\
\hline Localized (I-IIA) & $31(53)$ \\
\hline Advanced (IIB-IV) & $27(47)$ \\
\hline \multicolumn{2}{|l|}{ B symptoms } \\
\hline Yes & $31(53)$ \\
\hline No & $27(47)$ \\
\hline \multicolumn{2}{|l|}{ Bulky disease } \\
\hline Yes & $8(14)$ \\
\hline No & $50(86)$ \\
\hline \multicolumn{2}{|l|}{ Treatment } \\
\hline \multicolumn{2}{|l|}{ Chemotherapy } \\
\hline ABVD & $49(85)$ \\
\hline \multicolumn{2}{|l|}{ Relapsed } \\
\hline $\mathrm{ABVD}+\mathrm{COPP}$ & $6(10)$ \\
\hline $\mathrm{ABVD}+\mathrm{MOPP}$ & $3(5)$ \\
\hline Radiotherapy & $54(93)$ \\
\hline Chemotherapy only & $4(7)$ \\
\hline \multicolumn{2}{|l|}{ Response to treatment } \\
\hline Complete remission & $46(79)$ \\
\hline Relapse & $12(21)$ \\
\hline Number of deaths & $8(13.7)$ \\
\hline \multicolumn{2}{|c|}{ Composition of immune marker in HL samples } \\
\hline CD15 & $51(88)$ \\
\hline CD20 & $11(19)$ \\
\hline CD30 & $55(95)$ \\
\hline EBV & $20(35)$ \\
\hline
\end{tabular}


H-RS cells expressed LMP-1 in 20 (35\%) patients. LMP-1 was present in $10 / 20$ (50\%) patients with mixed cellularity and $8 / 29$ (28\%) patients with nodular sclerosis ( $\mathrm{P}>0.05)$. LMP-1 was expressed in 14/20 patients who were younger than 10 years and expressed in 6/38 patients who were older than 10 years $(\mathrm{P}=0.02)$. Positivity rate was higher in patients with advanced stage $(44 \%, \mathrm{P}>0.05)$. Otherwise, no associations were observed between the expression of LMP-1 and any clinical or histopathological features.
Complete remission was achieved in 46 (79\%) patients and progression in $12(21 \%)$ patients and death in $8(13.7 \%)$ patients. With a median follow-up of 4.5 years, OS at 5 years was 86.4\% for EBV LMP-1 positive patients [Standard error (SE) 9.4\%] and $84.8 \%$ for EBV LMP-1 negative patients (SE 7\%) (Figure 1 and Table 2).

FFS at 5 years are $80 \%$ for EBV LMP-1 positive patients (SE 8.9\%) and 84.2\% for EBV LMP-1 negative patients (SE 5.9\%) (Figure 2 and Table 3 ).

Table 2. Overall Survival at 5 Years

\begin{tabular}{lccc}
\hline Factor(s) & n & Death & 5y-OS\%(SE) \\
\hline LMP-1 & & 3 & 0.78 \\
Positive & 20 & 5 & $86.4 \%(9.4)$ \\
Negative & 38 & $84.8 \%(7.0)$ \\
\hline
\end{tabular}

Figure 1. Kaplan-Meier Overall Survival (OS) in 58 Children With EBV LMP-1 Positive and Negative Hodgkin Lymphoma

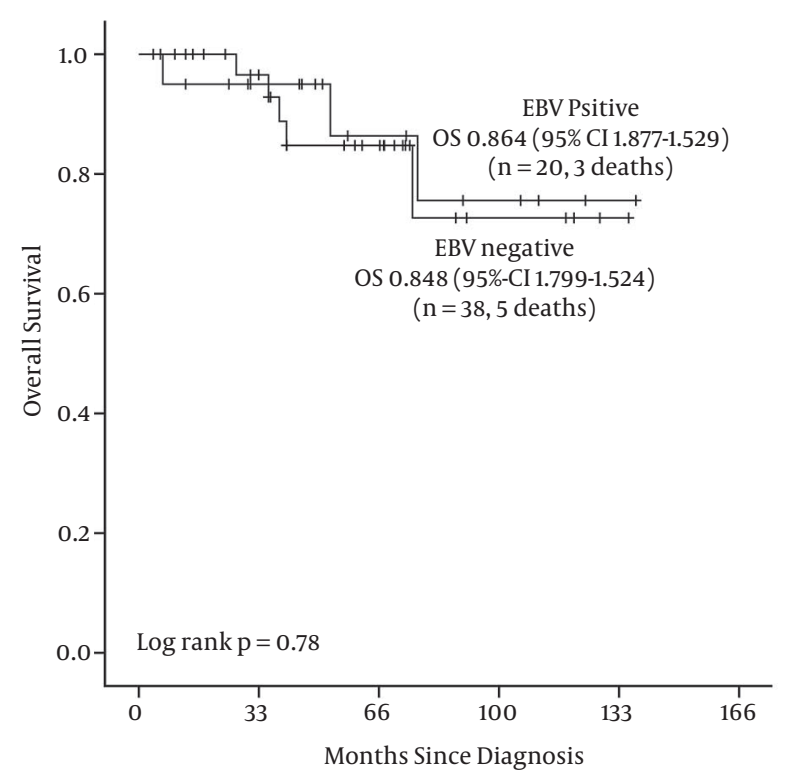

OS, overall survival; SE, standard error.
Figure 2. Kaplan-Meier Failure Free Survival (FFS) in 58 Children With EBV LMP-1 Positive and Negative Hodgkin Lymphoma

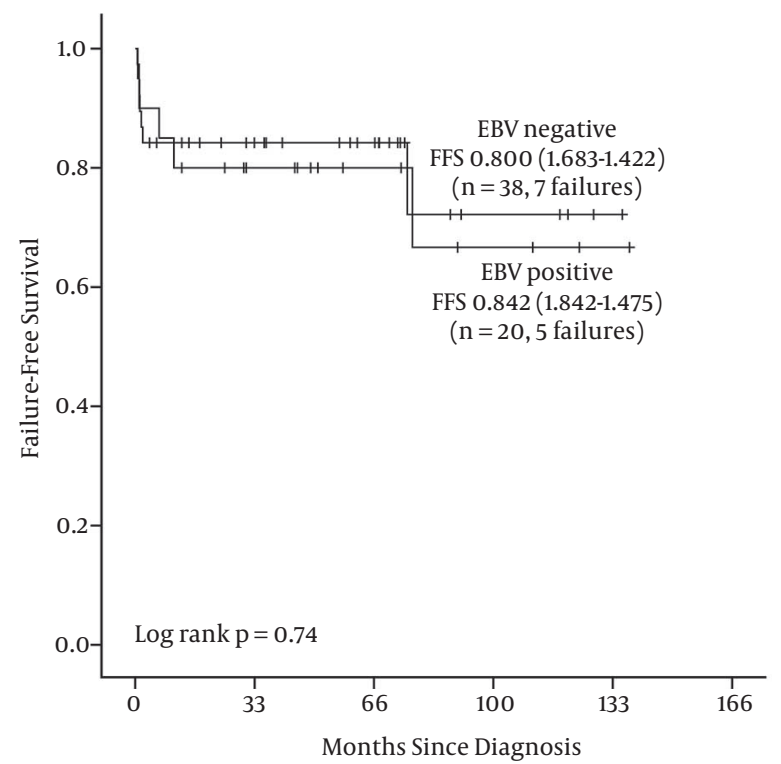

FFS, failure-free survival; SE, standard error.

Table 3. Failure Free Survival at 5 Years

\begin{tabular}{lccc}
\hline Factor(s) & $\mathbf{n}$ & Failure & 5y-FFS\%(SE) \\
\hline LMP-1 & & 5 & 0.74 \\
Positive & 20 & 7 & $80.0 \%(8.9)$ \\
Negative & 38 & $84.2 \%(5.9)$ \\
\hline
\end{tabular}




\section{Discussion}

We have paid attention to factors related to clinical course and etiopathogenesis of Hodgkin lymphoma and concluded that prognostic determinants associated with this disease are emerged from adult trials. Therefore we aimed to investigate EBV LMP-1 antibody in tissue of childhood HL.

The incidence of HL related to EBV differs from countries according to their socioeconomic level, ethnical and geographical features. In developing countries 90 percent of children under six years old suffer from EBV whereas in developed countries this ratio is 30\% - $40 \%$. Current trials show that H-RS cells are generally infected with EBV latently (9). In developed countries HL cases associated with EBV occur 30\% - 50\% (10, 11), whereas 80\% - $90 \%$ in developing countries $(9,12,13)$. In our HL cases EBV LMP-1 was found positive corresponding to 35 percen. EBV positiveness was also higher in patients under 10 years old $(\mathrm{P}=0.02)$. In our trial EBV positiveness ratios were similar to developed countries and we explained this result by patient enrollment. We considered that our patients diagnosed with HL were living in the neighborhood of Istanbul where socioeconomic status is high, so the incidence of patients infected by EBV was not common. As a consequence of this situation EBV LMP-1 was negative in $65 \%$ of patients. EBV LMP-1 positiveness is generally associated with mixed cellular type compatible as in our trial (10/20) (50\%) (14). Nodular sclerosing HL was the second most seen type with a ratio of $40 \%$. Cases were mostly classified as advanced stage and having B symptoms. EBV positiveness was not a significant factor for prognosis. Three EBV positive and 5 EBV negative patients died because of progression. Median survival time was 56 (6.6 - 138) months in EBV positive patients whereas 49 (4 -136) months in EBV negative patients and was not significant statistically.

Results of two different trials were consistent with our findings that EBV LMP-1 positiveness was not an important factor for prognosis of $\operatorname{HL}(15,16)$ whereas some trials showed that EBV was a negative indicator at the pathogenesis of HL $(17,18)$. Some studies concluded that EBV was a negative factor in advanced age and positive factor for young (19-21). It seems that the role of EBV in HL is still controversial (22). Expression of LMP-1 in HRS cells activates multiple signaling pathways, augments growth signals and inhibits apoptosis (19). In this sense, understanding the importance of latent EBV proteins as a prognostic factor in HL will make it possible to develop molecular targeted therapy.

In recent years, occurrence of disease and its refractoriness to treatment are challenging conditions for clinicians in terms of identifying strategies about maintenance therapy. Especially in early phase of the treatment, detection of new oncological molecules associated with high risk patients may be hopeful for increasing the ratios of treatment success. For this reason, investi- gation of EBV and other proto-oncogenes in tissues by immunohistochemical methods and understanding their prognostic importance can change treatment options. In real life, it is a truth that comprehensive clinical trials are needed for investigating the relationship between oncological molecules and prognosis in childhood HL (23).

This study may have some limitations. One of them is that although our cases included in this study were carrying the epidemiological features of our patient series, small case number may be considered a misleading condition about statistical significance.

\section{Acknowledgments}

This study was supported by Turkish pediatrics association, Istanbul, Turkey.

\section{Footnote}

Financial Disclosure:The authors declare that there is no conflict of interests regarding the publication of this article.

\section{References}

1. Hasenclever D, Diehl V. A prognostic score for advanced Hodgkin's disease. International Prognostic Factors Project on Advanced Hodgkin's Disease. N Engl J Med.1998;339(21):1506-14. doi: 10.1056/NEJM199811193392104. [PubMed: 9819449]

2. Morente MM, Piris MA, Abraira V, Acevedo A, Aguilera B, Bellas C, et al. Adverse clinical outcome in Hodgkin's disease is associated with loss of retinoblastoma protein expression, high Ki67 proliferation index, and absence of Epstein-Barr virus-latent membrane protein 1 expression. Blood. 1997;90(6):2429-36. [PubMed: 9310494]

3. Naresh KN, Johnson J, Srinivas V, Soman CS, Saikia T, Advani SH, et al. Epstein-Barr virus association in classical Hodgkin's disease provides survival advantage to patients and correlates with higher expression of proliferation markers in Reed-Sternberg cells. Ann Oncol. 2000;11(1):91-6. doi: 10.1023/a:1008337100424. [PubMed:10690394]

4. Enblad G, Sandvej K, Sundstrom C, Pallesen G, Glimelius B. Epstein-Barr virus distribution in Hodgkin's disease in an unselected Swedish population. Acta Oncol. 1999;38(4):425-9. [PubMed: 10418708]

5. Vestlev PM, Pallesen G, Sandvej K, Hamilton-Dutoit SJ, Bendtzen SM. Prognosis of Hodgkin's disease is not influenced by EpsteinBarr virus latent membrane protein. Int J Cancer. 1992;50(4):6701. [PubMed: 1311289]

6. Enblad G, Sandvej K, Lennette E, Sundström C, Klein G, Glimelius B, et al. Lack of correlation between EBV serology and presence of EBV in the Hodgkin and Reed-Sternberg cells of patients with Hodgkin's disease. In J Cancer. 1997;72(3):394-7. doi: 10.1002 (sici)1097-0215(19970729)72:3<394::aid-ijc3>3.3.co;2-0.

7. Axdorph U, Porwit-MacDonald A, Sjoberg J, Grimfors G, Ekman M Wang W, et al. Epstein-Barr virus expression in Hodgkin's disease in relation to patient characteristics, serum factors and blood lymphocyte function. Br J Cancer. 1999;81(7):1182-7. doi: 10.1038 sj.bjc.6690827. [PubMed:10584880]

8. Vassallo J, Metze K, Traina F, de Souza CA, Lorand-Metze I. Expression of Epstein-Barr virus in classical Hodgkin's lymphomas in Brazilian adult patients. Haematologica. 2001;86(11):1227-8. [PubMed: 11694413]

9. De Matteo E, Baron AV, Chabay P, Porta J, Dragosky M, Preciado MV Comparison of Epstein-Barr virus presence in Hodgkin lympho$\mathrm{ma}$ in pediatric versus adult Argentine patients. Arch Pathol Lab Med.2003;127(10):1325-9.doi:10.1043/1543-2165(2003)127<1325:CO- 
EVPI>2.0.CO;2. [PubMed:14521462]

10. Krugmann J, Tzankov A, Gschwendtner A, Fischhofer M, Greil $\mathrm{R}$, Fend $\mathrm{F}$, et al. Longer failure-free survival interval of EpsteinBarr virus-associated classical Hodgkin's lymphoma: a singleinstitution study. Mod Pathol. 2003;16(6):566-73. doi: 10.1097/01. MP.0000071843.09960.BF. [PubMed:12808062]

11. Glavina-Durdov M, Jakic-Razumovic J, Capkun V, Murray P. Assessment of the prognostic impact of the Epstein-Barr virus-encoded latent membrane protein-1 expression in Hodgkin's disease. $\mathrm{Br}$ Cancer. 2001;84(9):1227-34. doi: 10.1054/bjoc.2001.1774. [PubMed: 11336475]

12. Glaser SL, Lin RJ, Stewart SL, Ambinder RF, Jarrett RF, Brousset P, et al. Epstein-Barr virus-associated Hodgkin's disease: Epidemiologic characteristics in international data.IntJ Cancer.1997;70(4):37582. doi: 10.1002/(sici)1097-0215(19970207)70:4<375::aidijc1>3.3.co;2-1. [PubMed: 9033642]

13. Lee JH, Kim Y, Choi JW, Kim YS. Prevalence and prognostic significance of Epstein-Barr virus infection in classical Hodgkin's lymphoma: a meta-analysis. Arch Med Res. 2014;45(5):417-31. doi: 10.1016/j.arcmed.2014.06.001. [PubMed: 24937173]

14. Ping LY, Ding N, Shi YF, Sun L, Zheng W, Xie Y, et al. [Clinical characteristics and prognosis analysis of patients with LMP-1 positive Hodgkin's lymphoma after EBV infection]. Zhongguo Shi Yan Xue Ye Xue Za Zhi. 2014;22(1):78-84. doi: 10.7534/j.issn.10092137.2014.01.017. [PubMed: 24598656]

15. Herling M, Rassidakis GZ, Medeiros LJ, Vassilakopoulos TP, Kliche $\mathrm{KO}$, Nadali G, et al. Expression of Epstein-Barr virus latent membrane protein-1 in Hodgkin and Reed-Sternberg cells of classical Hodgkin's lymphoma: associations with presenting features, serum interleukin 10 levels, and clinical outcome. Clin Cancer Res. 2003;9(6):2114-20. [PubMed:12796376]

16. Spector N, Milito CB, Biasoli I, Luiz RR, Pulcheri W, Morais JC. The prognostic value of the expression of Bcl-2, p53 and LMP-1 in patients with Hodgkin's lymphoma. Leuk Lymphoma.
2005;46(9):1301-6. doi: 10.1080/10428190500126034. [PubMed: 16109607]

17. Claviez A, Tiemann M, Luders H, Krams M, Parwaresch R, Schellong $\mathrm{G}$, et al. Impact of latent Epstein-Barr virus infection on outcome in children and adolescents with Hodgkin's lymphoma. J Clin Oncol. 2005;23(18):4048-56. doi: 10.1200/JCO.2005.01.701. [PubMed:15961758]

18. Koh YW, Yoon DH, Suh C, Huh J. Impact of the Epstein-Barr virus positivity on Hodgkin's lymphoma in a large cohort from a single institute in Korea. Ann Hematol. 2012;91(9):1403-12. doi: 10.1007/s00277-012-1464-8. [PubMed: 22526365]

19. Kwon JM, Park YH, Kang JH, Kim K, Ko YH, Ryoo BY, et al. The effect of Epstein-Barr virus status on clinical outcome in Hodgkin's lymphoma. Ann Hematol. 2006;85(7):463-8. doi: 10.1007/s00277006-0081-9. [PubMed:16534596]

20. Keegan TH, Glaser SL, Clarke CA, Gulley ML, Craig FE, Digiuseppe JA, et al. Epstein-Barr virus as a marker of survival after Hodgkin's lymphoma: a population-based study. J Clin Oncol. 2005;23(30):7604-13. doi: 10.1200/JCO.2005.02.6310. [PubMed: 16186595]

21. Engel M, Essop MF, Close P, Hartley P, Pallesen G, Sinclair-Smith C. Improved prognosis of Epstein-Barr virus associated childhood Hodgkin's lymphoma: study of 47 South African cases. J Clin Pathol. 2000;53(3):182-6. [PubMed:10823135]

22. Mao Y, Lu MP, Lin H, Zhang da W, Liu Y, Li QD, et al. Prognostic significance of EBV latent membrane protein 1 expression in lymphomas: evidence from 15 studies. PLoS One. 2013;8(4):e2359. doi: 10.1371/journal.pone.0060313. [PubMed: 23613723]

23. Ishtiaq S, Hassan U, Mushtaq S, Akhtar N. Determination of frequency of epstein-barr virus in non- Hodgkin lymphomas Using EBV latent membrane protein 1 (EBV-LMP1) immunohistochemical staining. Asian Pac J Cancer Prev. 2013;14(6):3963-7. [PubMed: 23886215] 